\title{
ZINC FOR CHILD HEALTH IMPLICATIONS OF RESEARCH FINDINGS
}

\section{Chandyo R K*, Strand T A*}

\section{ABSTRACT}

Malnutrition and various micronutrient deficiencies are widespread in developing countries. Although the role of vitamin $\mathrm{A}$ and iron in child health has been acknowledged for a long time, the importance of zinc has not been recognized until recently. Indeed, zinc is a micronutrient of great public health importance. Recent research has indicated that prevention of zinc deficiency among young children in developing countries could have a significant impact on health as well as the economy.

In the near future, the World Health Organization (WHO) will recommend oral zinc for the treatment of acute and persistent diarrhea in young children. The WHO has also proposed to include zinc in its essential medicine list. Several key issues regarding zinc research and the impact of zinc on child health will be discussed in this paper.

\section{Key Words: Zinc, young children, diarrhea, child health, developing countries and Nepal.}

\section{INTRODUCTION}

Zinc is an essential micronutrient and zinc deficiency is common in many developing countries leaving those affected more vulnerable to illness and death from infectious diseases. ${ }^{1,2}$ In many developing countries the intake of zinc dense foods such as meat and seafood is low and the intake of foods with zinc inhibitors such as phytate in cereals and legumes, is high.${ }^{5}$ Frequent infections further impair the zinc status and worsen its consequences. This vicious cycle of sub-optimal nutrition and repeated infection results in a high burden of zinc deficiency in the developing countries, such as Nepal. The severe form of zinc deficiency leading to acrodermatitis enteropathica is not common, but marginal and moderate zinc deficiency is a widespread problem and is thought to affect more than $90 \%$ of the population in South Asia. ${ }^{6,7}$ In Nepal, two thirds of young children are malnourished. ${ }^{8}$ There is compelling evidence from animal and human studies that zinc is essential for the normal cellular function involved in growth and development, in the immune system, in cell division and in differentiation of skin and epithelial cells., ${ }^{9}, 10$ This paper will present recent evidence from studies of children in developing countries.

\section{ESTIMATION OF ZINC STATUS IN NEPAL}

Although the plasma zinc is sensitive to many conditions, such as stress, recent intake, dehydration and infection, ${ }^{11}$ it is still the most widely used method to determine zinc status in humans. The prevalence of zinc deficiency in Nepalese women and children based on plasma zinc levels was found to be $84 \%$ and $69 \%$, respectively, with a mean zinc concentration of 8.4 ? mol/L. ${ }^{12,13}$ It should be noted that the children of whom zinc was measured were ill with diarrhea, which may have influenced the plasma zinc concentration.

* Institute of Medicine, Maharajgunj, Kathmandu, Nepal.

** Center for International Health, University of Bergen, Armauer Hansen Building, N-5021, Bergen, Norway.

Address for correspondence : Dr. Ram Krishna Chandyo

CHRP, Field site

Siddhi Memorial Hospital

P.O. Box: 40, Bhaktapur, Nepal

Email: ram.chandyo@cih.uib.no 
TOXICITY OF ZINC

Zinc is a non-toxic mineral and excess dietary intake is not absorbed and stored in body. However, some studies have reported increased vomiting due to zinc supplementation. ${ }^{12,14}$ This increased vomiting was not serious and did not affect the long-term health of the children.

\section{ZINC FOR GROWTH AND DEVELOPMENT}

Zinc is thought to enhances growth and development through several potential mechanisms, which are presented in Fig. 1. ${ }^{15-17}$ In a meta-analysis undertaken by Brown et al, it was found that zinc supplementation resulted in a substantial increase in height and weight, the mean change in SD units height for age and weight for age was 0.35 (95\% CI 0.19 , $0.51)$ and $0.31(0.18,0.44)$, respectively. ${ }^{18}$ The effect of zinc supplementation was larger among children who were malnourished (stunted).

\section{PREVENTION OF DIARRHEA AND PNEUMONIA WITH ZINC}

Clinical trials in children of developing countries have shown that routine zinc supplementation reduces the incidence and prevalence of diarrhea. ${ }^{19,20}$ A pooled analysis of zinc supplementation trials from developing countries assessed the efficacy of daily zinc administration on diarrheal morbidity. This analysis showed an $18 \%$ (95\% CI 7\%, 28\%) lower incidence rate and a $25 \%(95 \%$ CI 12\%, 37\%) lower prevalence of diarrhea. ${ }^{21}$ This pooled analysis also included data for pneumonia from four trials ${ }^{22-25}$ and showed that routine zinc supplementation reduced the odds of pneumonia by $41 \%$ (95\% CI 17, 69\%). In a subsequent study involving 2500 Indian children, Bhandari et al confirmed this protective effect of daily zinc administration on pneumonia. ${ }^{19}$ In this study there was no effect of zinc supplementation on mild pneumonia, but the effect was seen among those with severe pneumonia that usually included fever. The main preventive zinc supplementation trials and their effects on infectious diseases and mortality prevalence are presented in Table I.

\section{TREATMENT OF DIARRHEA WITH ZINC}

Sachdev and coworkers were the first to assess the therapeutic effects of zinc during diarrhea. ${ }^{26}$ In a study on acute diarrhea they found that children who were given $40 \mathrm{mg}$ of daily elemental zinc had shorter diarrheal duration and lower stool frequency than the controls. Following this publication, several trials on zinc supplementation during acute and persistent diarrhea have been conducted and the results from many of these trials have been summarized in two pooled analyses. ${ }^{27}$ The analysis that included children with acute diarrhea showed that there was a $15 \%$ reduction of the duration in children receiving zinc (Table II) (Hazard ratio: $0.85,95 \%$ CI 0.76 , 0.95). In the trials that enrolled children with persistent diarrhea, therapeutic zinc reduced the time till recovery of diarrhea by $24 \%$ (Hazard ratio: $0.76,95 \%$ CI $0.63,0.91$ ) and the risk of treatment failure or death by $42 \%$ (95\% CI 10 , $63 \%)$ (Table III). ${ }^{27}$

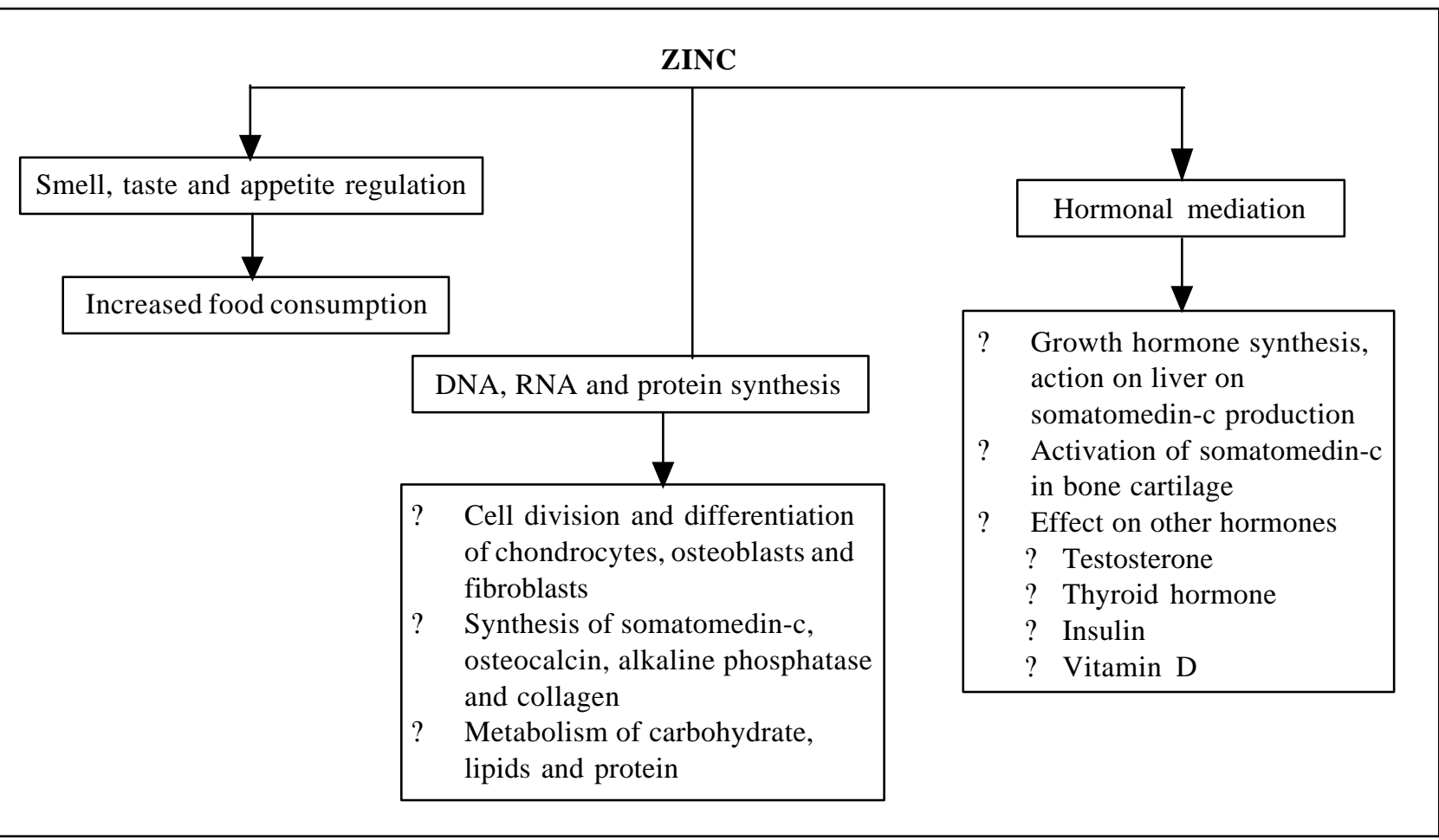

Fig. 1 : The mechanisms of zinc for growth and development (Reproduced from reference 15) 
Table I : Effects of zinc in prevention of diarrhea, pneumonia, malaria and mortality in children

\begin{tabular}{|c|c|c|c|c|c|}
\hline $\begin{array}{l}\text { Author, year } \\
\text { (Reference no) }\end{array}$ & Country & $\begin{array}{l}\text { Diarrhea } \\
\text { incidence } \\
(\% \text { lower })\end{array}$ & $\begin{array}{c}\text { Pneumonia } \\
\text { incidence } \\
(\% \text { lower })\end{array}$ & $\begin{array}{c}\text { Malaria } \\
\text { incidence } \\
\text { (\% lower) }\end{array}$ & $\begin{array}{l}\text { Mortality } \\
\text { incidence } \\
\text { (\% lower) }\end{array}$ \\
\hline Bates, 1993 [47] & The Gambia & & & 32 & \\
\hline Ninh, 1996[24] & Vietnam & $44^{1}$ & $44^{1}$ & & \\
\hline Rosado, 1997[48] & Mexico & 37 & & & \\
\hline Sazawal, 1998[25] [46] & India & 8 & $43^{1}$ & & $68^{1}$ \\
\hline Ruel, 1997 [49] & Guatemala & $18^{1}$ & & & \\
\hline Shankar, 2000[35] & Papua New Guinea & 12 & & $38^{1}$ & \\
\hline $\begin{array}{l}\text { Meek-Gardner, 1998[22] } \\
\text { Penny, 1999[23] } \\
\text { Umeta, 2000 [50] } \\
\text { Muller, 2001 [51] } \\
\text { Bhandari, 2002[19] }\end{array}$ & $\begin{array}{l}\text { Jamaica } \\
\text { Peru } \\
\text { Ethiopia } \\
\text { Burkina Faso } \\
\text { India }\end{array}$ & $\begin{array}{c}8 \\
12^{1} \\
55^{1} \\
16^{1}\end{array}$ & $\begin{array}{c}88 \\
15 \\
\\
57 \\
26^{1} \\
\end{array}$ & 2 & 58 \\
\hline
\end{tabular}

${ }^{1}$ Statistically significant, i.e. $p<0.05$

(Reproduced from reference 6)

Table II : Studies evaluating therapeutic effects of zinc supplementation in the treatment of acute diarrhea

\begin{tabular}{|c|c|c|c|c|}
\hline $\begin{array}{l}\text { Author, year } \\
\text { (Reference no) }\end{array}$ & Country & $\begin{array}{l}\text { No. of subjects } \\
\text { zinc/placebo }\end{array}$ & $\begin{array}{l}\text { Dose of zinc } \\
\text { (elemental) }\end{array}$ & $\begin{array}{l}\text { Difference in mean } \\
\text { duration in days } \\
(95 \% \mathrm{CI})\end{array}$ \\
\hline Sachdev, 1988 [26] & India & $25 / 25$ & $40 \mathrm{mg}$ & $-0.4(-1.4,0.6)$ \\
\hline Faruque, 1999 [52] & Bangladesh & $341 / 340$ & 14.2 or $40 \mathrm{mg}$ & $-1.0(-1.8,-0.2)$ \\
\hline Dutta, 2000 [53] & India & $44 / 36$ & $40 \mathrm{mg}$ & $-1.4(-1.6,-1.1)$ \\
\hline Sazawal, 2001 & India & $547 / 547$ & 5 or $10 \mathrm{mg}$ & $0.1(-0.2,0.3)$ \\
\hline Cuevas, 2001 & Brazil & $37 / 37$ & 22.5 or $45 \mathrm{mg}$ & $\begin{array}{c}-1.3(-1.9,-0.6) \\
\text { Relative Hazards } \\
(95 \% \text { CI })\end{array}$ \\
\hline Hidayat, 1998 [54] & Indonesia & $739 / 659$ & $4.5 \mathrm{mg} / \mathrm{kg}$ & $0.92(0.83,1.02)$ \\
\hline Sazawal, 1997 [20] & India & $456 / 481$ & $20 \mathrm{mg}$ & $0.79(0.69,0.90)$ \\
\hline Roy, 1997 [55] & Bangladesh & $57 / 54$ & $20 \mathrm{mg}$ & $0.85(0.57,1.28)$ \\
\hline Bhatnagar, 2004 [29] & India & $132 / 134$ & 15 or $30 \mathrm{mg}$ & $0.77(0.59,0.99)$ \\
\hline Bahl, $2002[14]$ & India & $404 / 401$ & 15 or $30 \mathrm{mg}$ & $0.89(0.80,0.99)$ \\
\hline Strand, 2002 [12] & Nepal & $442 / 449$ & 15 or $30 \mathrm{mg}$ & $0.79(0.68,0.93)$ \\
\hline Baqui, 2002 [32] & Bangladesh & $620 / 632$ & $20 \mathrm{mg}$ & $0.77(0.69,0.86)$ \\
\hline
\end{tabular}

(Reproduced from reference 30 )

Table III : Studies evaluating therapeutic effects of zinc on episodes of prolonged diarrhea (>7 days)

\begin{tabular}{l|l|c|cc}
\hline $\begin{array}{c}\text { Author, year } \\
\text { (Reference no) }\end{array}$ & \multicolumn{1}{|c|}{ Country } & $\begin{array}{c}\text { No. of subjects } \\
\text { zinc/placebo }\end{array}$ & $\begin{array}{c}\text { Dose of zinc } \\
\text { (elemental) }\end{array}$ & $\begin{array}{c}\text { Odds ratio } \\
\text { (95\% CI) }\end{array}$ \\
\hline Hidayat, 1998[54] & Indonesia & $739 / 659$ & $4.5 \mathrm{mg} / \mathrm{kg}$ & $0.72(0.48,1.07)$ \\
\hline Sazawal, 1997[20] & India & $456 / 481$ & $20 \mathrm{mg}$ & $0.85(0.60,1.19)$ \\
\hline Roy, 1997[55] & Bangladesh & $57 / 54$ & $20 \mathrm{mg}$ & $0.77(0.33,1.79)$ \\
\hline Bahl, 2002[14] & India & $404 / 401$ & $15 \mathrm{or} 30 \mathrm{mg}$ & $0.61(0.33,1.12)$ \\
\hline Strand, 2002[12] & Nepal & $442 / 449$ & 15 or $30 \mathrm{mg}$ & $0.57(0.38,0.86)$ \\
\hline
\end{tabular}

(Reproduced from reference 30)

After these pooled analyses were published, more studies on the therapeutic use of zinc in diarrhea have been completed. ${ }^{12,14,28,29}$ The findings from these studies were presented in a WHO meeting in New Delhi in 2001 and the report from this meeting ${ }^{30}$ states: "Based on the results of this review, it is concluded that there is now enough evidence demonstrating the efficacy of zinc supplementation on the clinical course of diarrhea, with regard to the severity and duration of the episode".

The results from a trial we undertook in 1,792 Nepalese children aged 6 to 35 months with acute diarrhea were included in this report. ${ }^{12}$ In this trial the risk of persistent diarrhea was reduced from $5.2 \%$ to $2.7 \%$, corresponding to a risk reduction of $2.5 \%(95 \%$ CI $0.2 \%, 5 \%)$ in those given zinc. ${ }^{31}$ A nearly fifty percent reduction in the risk of persistent diarrhea is indeed 
promising and is supported by a recently published clusterrandomized trial in Bangladeshi children. ${ }^{32}$ This study also showed that there was a $50 \%$ reduction in mortality in clusters where children were given zinc along with standard treatment against diarrhea. It should be noted that there were only 40 fatalities and that children in the clusters that received zinc also had a higher intake of ORS. ${ }^{30}$

\section{ZINC AS ADJUVANT THERAPY FOR THE TREATMENT OF PNEUMONIA}

Studies on routine zinc supplementation for the prevention of disease indicated substantial reductions in the prevalence of acute lower respiratory infection (ALRI). There is, however, limited information on zinc as adjuvant therapy for the treatment of ALRI. In a pneumonia study with Indian children there was an effect of zinc among boys, but not among girls. ${ }^{33}$ Another recently published study from Bangladesh among 270 young children with severe pneumonia indicated that zinc supplementation reduced the duration ?relative hazard $(\mathrm{RH})=$ $0.70(0.51,0.98)$ ? and hospital stay ?(RH $0.75(0.57-0.99) ?^{34}$ Currently, we are undertaking a randomized clinical trial in Bhaktapur involving 2500 young children with WHO defined pneumonia to evaluate the effect of zinc as an adjuvant therapy. The main outcome is time till recovery and proportion with treatment failure.

\section{ZINC SUPPLEMENTATION FOR THE TREATMENT AND PREVENTION OF MALARIA}

The results from studies evaluating the relation between zinc supplementation for the prevention and treatment of malaria are still inconclusive. Studies from Gambia and Papua New Guinea $^{35}$ revealed reductions of about one-third in the rate of visits to health facilities due to malaria among zinc supplemented children. However, a multicenter trial in Ecuador, Uganda and Zambia that assessed zinc as adjuvant therapy during plasmodium falciparum malaria in 1087 young children concluded that, "Zinc does not appear to provide a beneficial effect in the treatment of acute, uncomplicated falciparum malaria". 36

\section{ZINC AND IMMUNITY}

Zinc supplementation has been shown to improve cell mediated immunity (CMI) in children. ${ }^{20}$ Besides effect on CMI, the roles of zinc in modulating phagocytes and NK cell activity are also well described. ${ }^{37-39}$ The size of thymus, which is a central organ for maturation and differentiation of T-lymphocytes also decrease during zinc deficiency, a process that is reversed after zinc supplementation. ${ }^{40,41}$ Although both acquired and innate immunity seems to play an important role in the effect of zinc during infections, ${ }^{42,43}$ the relative importance of these parts of the immune system remains to be determined. Furthermore, zinc metabolism is altered in infectious diseases. During inflammation, the plasma zinc is shifted into the liver causing depletion in other tissues. ${ }^{44}$ Children who have poor zinc nutriture may thus be at a high risk of entering a vicious cycle of infection and zinc depletion. Breaking this vicious cycle is probably of great importance and may be the mechanism behind the beneficial effect on reduction of childhood morbidity and mortality.

\section{ZINC FOR THE REDUCTION OF CHILDHOOD MORTALITY}

As mentioned above, zinc administration in children of developing countries have shown a substantial reduction in the prevalence and severity of common infectious diseases such as pneumonia and diarrhea. Pneumonia and diarrhea are still major causes of under five-childhood mortality, so it is logical to consider that there will be a reduction in childhood mortality with a correction of zinc deficiency. Indeed, the Bellagio child survival study estimates that $5 \%$ of under five deaths can be averted by the implementation of a preventive zinc interventions program. ${ }^{45}$ This figure is supported by the findings from a trial in 1,154 small for gestational age children where zinc supplementation resulted in a $68 \%$ reduction in the risk of dying. ${ }^{46}$ A reduced death risk was also found among children belonging to clusters that received zinc as adjuvant therapy for acute diarrhea trial in Bangladesh. ${ }^{32}$ The WHO has followed up the promising results of these trials and is currently supporting three large clinical trials in India, Zanzibar and Nepal to evaluate the effect of zinc supplementation on childhood mortality.

Thus, there is compelling evidence that zinc is beneficial for the improvement of child health, particularly in developing countries where zinc deficiency is estimated to be a widespread public health problem. Oral zinc should be included in routine treatment for acute diarrhea and actions to improve zinc nutriture should be pursued. These actions would include dietary diversification / modification to enhance the availability, access and utilization of zinc dense foods, food fortification, supplementation, and most importantly, poverty reduction.

\section{REFERENCES}

1. Baqui, A.H., et al., Simultaneous weekly supplementation of iron and zinc is associated with lower morbidity due to diarrhea and acute lower respiratory infection in Bangladeshi infants. J Nutr, 2003. 133 (12) : p. 4150-7.

2. Bahl, R., et al., Plasma zinc as a predictor of diarrheal and respiratory morbidity in children in an urban slum setting. Am J Clin Nutr, 1998. 68 (2 Suppl) : p. 414S-417S. 
3. Gibson, R.S. and J.M. Huddle, Suboptimal zinc status in pregnant Malawian women: its association with low intakes of poorly available zinc, frequent reproductive cycling, and malaria. Am J Clin Nutr, 1998. 67 (4) : p. 702-9.

4. Ellis, R., et al., Phytate:zinc andphytateX calcium:zincmillimolar ratios in self-selected diets of Americans, Asian Indians, and Nepalese. JAmDiet Assoc, 1987. 87 (8) : p. 1043-7.

5. Lonnerdal, B., Dietary factors influencing zinc absonption. $J$ Nutr, 2000. 130 (5S Suppl) : p. 1378S-83S.

6. Black, R.E., Zinc deficiency, infectious disease andmortality in the developing world. J Nutr, 2003. 133 (5 Suppl 1) : p. 1485s9S.

7. Black, R.E. and S. Sazawal, Zinc and chilohood infectious disease morbidity and mortality. Br J Nutr, 2001. 85 Suppl 2: p. S125-9.

8. NMSS, Nepal Micronutrient Status Survey, 1998.

9. Karlsen, T.H., et al., Intestinal and systemic immune responses to an oral cholera toxoid B subunit whole-cell vaccine administered during zinc supplementation. Infect Irmun, 2003. 71 (7) : p. 3909-13.

10. Fraker, P.J., et al., The dynamic link between the integrity of the immune system and zinc status. J Nutr, 2000. 130 (5S Suppl) : p. 1399S-406S.

11. Strand, T.A., et al., Predictors of plasma zinc concentrations in children with acute diarrhea. Am J Clin Nutr, 2004. 79 (3): p. 451-6.

12. Strand, T.A., et al., Effectiveness and efficacy of zinc for the treatment of acute diarrhea in young children. Pediatrics, 2002. $109(5):$ p. 898-903.

13. Christian, P., et al., Zinc supplementation might potentiate the effect of vitamin $A$ in restoring night vision in pregnant Nepalese women. Am J Clin Nutr, 2001. 73 (6) : p. 1045-51.

14. Bahl, R., et al., Efficacy of zinc-fortified oral rehydration solution in 6- to 35-month-old children with acute diarmea. JPediatr, 2002. $141(5):$ p. 677-82.

15. Salgueiro, M.J., et al., The role of zinc in the growth and development of children. Nutrition, 2002. 18(6) : p. 510-9.

16. Brandao-Neto, J., et al., Endocrine interaction between zinc and prolactin. An interpretative review. Biol Trace Elem Res, 1995. $49(2-3):$ p. 139-49.

17. Ploysangam, A., G.A. Falciglia, and B.J. Brehm, Effect of marginal zinc deficiency on human growth and development. J Trop Pediatr, 1997. $43(4)$ : p. 192-8.

18. Brown, K.H., et al., Effect of supplemental zinc on the growth and serum zinc concentrations of prepubertal children: a metaanalysis of randomized controlled trials. Am J Clin Nutr, 2002. $75(6)$ : p. 1062-71.

19. Bhandari, N., et al., Effect of routine zinc supplementation on pneumonia in children aged 6 months to 3 years: randomised controlled trial in an urban slum. BMJ, 2002. 324 (7350): p. 1358.
20. Sazawal, S., et al., Efficacy of zinc supplementation in reducing the incidence and prevalence of acute diarrhea-a communitybased, double-blind, controlled trial. Am J Clin Nutr, 1997. $66(2)$ : p. 413-8.

21. Bhutta, Z.A., et al., Prevention of diarrhea and pneumonia by zinc supplementation in children in developing countries: pooled analysis of randomized controlled trials. Zinc Investigators' Collaborative Group. J Pediatr, 1999. 135 (6) : p. 689-97.

22. Meeks Gardner, J., M.M. Witter, and D.D. Ramdath, Zinc supplementation: effects on the growth and morbidity of undernourished Jamaican children. Eur J Clin Nutr, 1998. $52(1)$ : p. 34-9.

23. Penny, M.E., et al., Randomized, community-based trial of the effect of zinc supplementation, with and without other micronutrients, on the duration of persistent childhood diarrhea in Lima, Peru. JPediatr, 1999. 135 (2 Pt 1) : p. 20817.

24. Ninh, N.X., et al., Zinc supplementation increases growth and circulating insul in-like gronth factor I (IGF-I) in growth-retarded Vietnamese children. Am J Clin Nutr, 1996. 63 (4) : p. 514-9.

25. Sazawal, S., et al., Zinc supplementation reduces the incidence of acute lower respiratory infections in infants and preschool children: a double-blind, controlled trial. Pediatrics, 1998. $102(1$ Pt 1) : p. 1-5.

26. Sachdev, H.P., et al., A controlled trial on utility of oral zinc supplementation in acute dehydrating diarrhea in infants. $J$ Pediatr Gastroenterol Nutr, 1988. 7 (6) : p. 877-81.

27. Bhutta, Z.A., et al., Therapeutic effects of oral zinc in acute and persistent diarrhea in children in developing countries: pooled analysis of randomized controlled trials. Am JCl in Nutr, 2000. $72(6):$ p. 1516-22.

28. Al-Sonboli, N., et al., Zinc supplementation in Brazilian children with acute diarrhoea. Ann Trop Paediatr, 2003. 23 (1) : p. 3-8.

29. Bhatnagar, S., et al., Zinc with oral rehydration therapy reduces stool output and duration of diarrhea in hospitalized children: a randomized controlled trial. JPediatr Gastroenterol Nutr, 2004. 38 (1) : p. 34-40.

30. Fontaine, O., Report of a meeting, New Delhi, 7-8 May 2001. Effect of zinc supplementation on clinical course of acute diarrhea. J. Health Popul. Nutr, 2001. 19: p. 338-346.

31. Strand, T., Zinc and Infectious Disease- studies of mice and men, in PhD thesis. 2003, University of Bergen, Norway: Bergen.

32. Baqui, A.H., et al., Effect of zinc supplementation started during diarrhoea on morbidity and mortality in Bangladeshi children: community randomised trial. BMJ, 2002. 325 (7372) : p. 1059.

33. Mahalanabis, D., et al., Zinc supplementation as adjunct therapy in children with measles accompanied by pneumonia: a double-blind, randomized controlled trial. Am J Cl in Nutr, 2002. $76(3):$ p. 604-7. 
34. Brooks, W.A., et al., Zinc for severe pneumonia in very young children: double-blind placebo-controlled trial. Lancet, 2004. $363(9422)$ : p. 1683-8.

35. Shankar, A.H., Nutritional modulation of malaria monbidity and mortality. J Infect Dis, 2000. 182 Suppl 1: p. S37-53.

36. Zinc, Effect of zinc on the treatment of Plasmodium falciparum malaria in children: a randomized controlled trial. Am JClin Nutr, 2002. 76: p. 805-12.

37. Fan, P.C., et al., Impaired immune function in a premature infant with zinc deficiency after total parenteral nutrition. Zhonghua Min Guo Xiao Er Ke Yi Xue Hui Za Zhi, 1996. 37 (5) : p. 364-9.

38. Abul, H.T., et al., Interleukin-1 alpha (II-1 alpha) production by alveolar macrophages in patients with acute lung diseases: the influence of zinc supplementation. Mol Cell Biochem, 1995. $146(2):$ p. 139-45.

39. Salgueiro, M.J., et al., Zinc status and immune system relationship: a review. Biol Trace Elem Res, 2000. 76 (3) : p. 193-205.

40. Parent, G., et al., In vitro lymphocyte-differentiating effects of thymulin (Zn-FTS) on lymphocyte subpopulations of severely malnourished children. Am J Clin Nutr, 1994. 60 (2) : p. 2748.

41. Chevalier, P., Zinc and duration of treatment of severe malnutrition. Lancet, 1995. 345 (8956) : p. 1046-7.

42. Roy, S.K., et al., Impact of zinc supplementation on intestinal permeability in Bangladeshi children with acute diarrhoea and persistent diarrhoea syndrome. J Pediatr Gastroenterol Nutr, 1992. 15 (3) : p. 289-96.

43. Albert, M.J., et al., Supplementation with zinc, but not vitamin A, improves seroconversion to vibriocidal antibody in children given an oral cholera vaccine. J Infect Dis, 2003. 187 (6) : p. 909-13.

44. Cousins, R.J. and A.S. Leinart, Tissue-specific regulation of zinc metabolism and metallothionein genes by interleukin 1 . Faseb J, 1988. 2 (13) : p. 2884-90.
45. Jones, G., et al., How many child deaths can we prevent this year? Lancet, 2003. 362 (9377) : p. 65-71.

46. Sazawal, S., et al., Zinc supplementation in infants bom small for gestational age reduces mortality: a prospective, randomized, controlled trial.Pediatrics, 2001. 108 (6) : p. $1280-6$.

47. Bates, C.J., et al., A trial of zinc supplementation in young nural Gambian children. Br J Nutr, 1993. 69 (1) : p. 243-55.

48. Rosado, J.L., et al., Zinc supplementation reduced monbidity, but neither zinc nor iron supplementation affected growth or body composition of Mexican preschoolers. Am J Clin Nutr, 1997. 65 (1) : p. 13-9.

49. Ruel, M.T., et al., Impact of zinc supplementation on morbidity from diarrhea and respiratory infections among rural Guatemalan children. Pediatrics, 1997. 99(6) : p. 808-13.

50. Umeta, M., et al., Zinc supplementation and stunted infants in Ethiopia: a randomised controlled trial. Lancet, 2000. $355(9220)$ : p. 2021-6.

51. Muller, O., et al., Effect of zinc supplementation on malaria and other causes of morbidity in west African children: randomised double blind placebo controlled trial. BM, 2001. $322(7302)$ : p. 1567.

52. Faruque ASG, M.D., Haque SS, Fuch GJ, Habte D, Doubleblind, randomized, controlled trial of zinc or vitamin A supplementation in young children with acute diarrhea. Acta Paediatr, 1999. 88: p. 154-60.

53. Dutta, P., et al., Impact of zinc supplementation in malnourished children with acute watery diarrhoea. J Trop Pediatr, 2000. $46(5)$ : p. 259-63.

54. Hidayat, A., Achadi, A, Sunoto, Soedarno SP, The effect of zinc supplementation in children under three years of age with acute diarrhea in Indonesia. Med J Indonesia, 1998. 7: p. 237-41.

55. Roy, S.K., et al., Randomised controlled trial of zinc supplementation in malnourished Bangladeshi children with acute diarrhoea. Arch Dis Child, 1997. 77 (3) : p. 196-200.

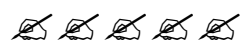

